\title{
FLOW CHANGES IN ORBITAL VESSELS DETECTED WITH COLOR DOPPLER ULTRASOUND IN PATIENTS WITH EARLY DYSTHYROID OPTIC NEUROPATHY
}

\author{
Mladen Lešin ${ }^{1}$, Veljko Rogošić ${ }^{1}$, Lucija Vanjaka Rogošić ${ }^{2}$, Igor Barišić ${ }^{3}$ and Goran Pelčić ${ }^{4}$ \\ ${ }^{1}$ Department of Ophthalmology, Split University Hospital Center, Split, Croatia; \\ ${ }^{2}$ Dr. Vanjaka Rogošić Dermatovenereological Surgery, Split, Croatia; \\ ${ }^{3}$ Department of Radiology, Split University Hospital Center, Croatia; \\ ${ }^{4}$ Department of Ophthalmology, Rijeka University Hospital Center, Rijeka, Croatia
}

\begin{abstract}
SUMMARY - Thyroid-associated orbitopathy (TAO) is a common manifestation of Graves' disease. The aim of the study was to assess the six percent of patients with TAO that develop dysthyroid optic neuropathy (DON), which is the most serious complication of TAO. As DON can cause permanent damage, it is essential to detect DON early when visual loss is still reversible. Color Doppler ultrasound is a noninvasive diagnostic method, which may be useful in early detection of DON. Thirty-six patients with confirmed Graves' disease and active TAO were included, 21 (58\%) of them with early DON (eDON) and $15(42 \%)$ free from any signs of eDON. All study patients underwent Doppler ultrasound examination to determine the blood flow rates in the internal carotid artery, ophthalmic artery, and central retinal artery. Study results showed color Doppler ultrasound examination to have a potential to detect orbital blood flow changes in patients with eDON. Early detection of DON may result in earlier treatment and prevention of permanent optic nerve damage.
\end{abstract}

Key words: Graves' Ophthalmopathy; Graves' Disease; Optic Nerve Diseases; Ultrasonography, Doppler, Color; Optic Nerve Injuries

\section{Introduction}

Thyroid-associated orbitopathy (TAO) is a common manifestation of Graves' disease. TAO may be caused by high levels of circulating thyroid-stimulating immunoglobulins, T-cell activation and orbital fibroblast activation, and it is characterized by edema and infiltration of extraocular muscles and other orbital tissues ${ }^{1,2}$.

Six percent of patients with TAO develop dysthyroid optic neuropathy (DON); compression of the optic nerve by enlarged orbital tissues in the orbital apex

Correspondence to: Assist. Prof. Veljko Rogošic, $M D, P h D$, Split University Hospital Center, Department of Ophthalmology, Spinčićeva 1, HR-21000 Split, Croatia

E-mail: veljko.rogosic@st.t-com.hr

Received November 2,2016, accepted September 6, 2017 likely accounts for the majority of these cases ${ }^{3}$. DON is the most serious complication of TAO because it can cause permanent visual impairment and blindness in $30 \%$ of affected patients ${ }^{4}$. As DON can cause permanent damage, it is essential to detect DON as early as possible, when visual loss is still reversible and when appropriate therapy may result in full or substantial recovery of visual function ${ }^{5}$.

Unfortunately, DON is very difficult to diagnose in a timely fashion because its signs and symptoms (decreased visual acuity, relative afferent pupillary defect, edema of the optic nerve head, visual field defects, and color vision impairment) are often subtle and can therefore be missed if they are not screened for specifically $^{1,6}$. Clinical assessment of DON should determine the occurrence of symptoms such as blurring, color desaturation, or the appearance of grey spots, 
testing of visual acuity, color discrimination and relative pupillary defect, and should include funduscopy to determine disc appearance and the presence of choroidal folds. Optional investigations include perimetry, contrast sensitivity testing, electrodiagnostic tests, and imaging to look for apical crowding ${ }^{6}$. Currently, there is no standard criterion to base the diagnosis, especially in cases of early DON (eDON).

Patients with DON and visual acuity measuring under 0.7 have never regained normal visual acuity (1.0), and other clinical parameters have not normalized after treatment ${ }^{7}$. This suggests that the impairment of optic nerve function occurs before the appearance of the first clinical signs 8 .

Visual acuities of 0.5 or better are present in 50\%$70 \%$ of eyes with DON 9 . In addition, there is clear evidence that DON can be present even with normal vision ${ }^{10}$. In some patients, visual acuity of 1.0 may already represent reduction in their normal visual acuity, whereas in other patients, visual acuity is still unaffected at the time DON is diagnosed.

A number of noninvasive diagnostic methods for detecting eDON have shown some potential, such as visual evoked potentials (VEP), contrast sensitivity testing, and perimetry ${ }^{10}$. Color Doppler ultrasound is another noninvasive diagnostic method that offers quantitative analysis of blood flow; it can detect small subclinical changes in flow rates even in vessels with very low blood flow, such as orbital vessels. To our knowledge, only two reports on color Doppler ultrasound of orbital vasculature in patients with Graves' disease have been published ${ }^{11,12}$. Therefore, this study aimed to investigate diagnostic potential of color Doppler ultrasound of orbital vessels in detecting eDON. We used color Doppler to measure orbital circulation parameters and to examine the primary hypothesis that $\mathrm{eDON}$ is associated with significant changes in orbital blood flow.

\section{Patients and Methods}

This was a cohort study that included 36 patients with confirmed Graves' disease, from the Endocrinology Department, Split University Hospital Center, Split, Croatia. Study patients were divided into two groups according to contrast sensitivity testing and static perimetry results. The first group of $21(58 \%) \mathrm{pa}^{-}$ tients had eDON (patients with eDON had patho- logic contrast sensitivity and static perimetry test results), while second group of 15 (42\%) patients had no signs of DON (normal contrast sensitivity and static perimetry results). We enrolled both men and women aged 35 to 60 years. All patients had previously been diagnosed with Graves' disease, had best corrected visual acuity (BCVA) $\geq 0.7$ (Snellen chart), enlarged extraocular muscles on multi-slice computed tomography (MSCT) scans, and active TAO confirmed by a clinical activity score $\geq 4^{13}$. We excluded all patients with congenital or pathologic color vision disturbances, relative afferent pupillary defects, edematous or pale optic nerve heads, as well as patients with glaucoma, ocular hypertension, patients with ocular surface diseases, previous eye or orbital surgeries and other diseases of the eye, optic nerve or orbit. The research was performed at the Ophthalmology, Neurology, and Radiology Departments, Split University Hospital Center, Split, Croatia.

The following examinations were performed in all study patients: central visual acuity testing (Snellen charts); contrast sensitivity testing (CST) with Ginsburg's test CST-1800 (Vision Sciences Research Corporation, San Ramon, USA); indirect dilated ophthalmoscopy; intraocular pressure measurement with Goldmann's applanation tonometry; Hertell's exophthalmometry; static perimetry (Standard Examination Programs/normal examination with 76 locations) on the Octopus 101 (Haag Streit USA, Mason, OH, USA); color Doppler examination of the blood flow rate in the internal carotid artery (ICA), ophthalmic artery (OA), and central retinal artery (CRA) using SONO ACE $6000 \mathrm{C}$ ultrasound (Medison Austria, South Korea) and a 7.5 MHz linear probe; and MSCT scans of the orbit to determine the volume change in extraocular muscles and orbital fatty tissue.

We considered the patient to have eDON if the mean defect value of the visual field testing was higher than 4 (normal values from -2 to 2 ) and CST curve passed beneath 5.5 cycles per degree (C/D) for low and medium frequencies and beneath $2.0 \mathrm{C} / \mathrm{D}$ for high frequencies on three occasions.

Data were expressed as mean \pm standard deviation for continuous variables and percentages for categorical variables. For distribution evaluation, we used descriptive statistics methods, and normal data distribution was verified by Kolomogorov-Smirnov test. We used $\chi^{2}$-test to determine the association between gen- 
der and eDON. Difference in blood flow parameters and age between the two groups of patients was tested by Mann-Whitney U test or two-tailed Student's ttest for unmatched samples, depending on the characteristics of distribution. The receiver operating characteristic curve (ROC) and logistic regression were used in the analysis of prognostic values of individual parameters for eDON (blood flow, age, contrast sensitivity and visual fields). Spearman coefficient of correlation was used on bivariate correlation analysis of flow parameters and contrast sensitivity test results. In all tests, we set the level of significance at $\alpha=0.05$. All statistical analyses were performed using the SPSS, version 13 (SPSS, Inc., Chicago, IL, USA) software.

\section{Results}

In this study, 36 patients were enrolled, 21 (58\%) of them diagnosed with eDON. All patients were aged between 36 and 57 years (mean $\pm \mathrm{SD}=50.16 \pm 6.43$ ). There were eight (22\%) male and 28 (78\%) female patients. Despite the large number of female patients in both groups, no differences related to age distribution and sex were found $\left(\chi^{2}=4.876 ; d f=1 ; p=0.003\right)$.
There were no significant between-group differences in Doppler ultrasound parameters for the ICA, although the pulsatility index showed higher mean values with borderline significance in the group without eDON (Table 1). However, when compared with eDON patients, the group without eDON had significantly higher Doppler ultrasound parameters for the OA (peak systolic flow velocity $\mathrm{p}=0.019$, mean flow $\mathrm{p}=0.013$ ) and for the CRA (peak systolic flow velocity $\mathrm{p}=0.010$, end diastolic flow velocity $\mathrm{p}<0.001$, resistivity index $\mathrm{p}=0.009$ ).

We also tested for correlation between all Doppler ultrasound parameters with contrast sensitivity results or with visual field results (Table 2). For the ICA, we found a strong positive correlation between the peak systolic flow velocity and contrast sensitivity test results $(\mathrm{r}=0.54 ; \mathrm{p}=0.001)$, as well as between the mean flow and contrast sensitivity test results $(r=0.37$; $\mathrm{p}=0.027$ ). There was no significant correlation with visual field results. For the OA, we found a significant negative correlation between the contrast sensitivity results and peak systolic flow velocity $(\mathrm{r}=-0.35 ; \mathrm{p}=$ $0.038)$, end diastolic flow velocity $(r=-0.44 ; p=0.008)$, and mean flow $(r=-0.43 ; \mathrm{p}=0.009)$. Additionally, there

Table 1. Doppler ultrasound parameter mean values for examined arteries in patients with and without early dysthyroid optic neuropathy (eDON)

\begin{tabular}{|c|c|c|c|c|c|}
\hline & & \multicolumn{2}{|c|}{ Group } & \multirow[b]{2}{*}{$\mathrm{t}$-value ${ }^{\dagger}$} & \multirow[b]{2}{*}{$\mathrm{p}$-value } \\
\hline Artery & $\begin{array}{l}\text { Doppler ultrasound } \\
\text { parameter }\end{array}$ & $\begin{array}{l}\text { eDON } \\
(\Delta \pm \mathrm{SD})\end{array}$ & $\begin{array}{l}\text { No eDON } \\
(\Delta \pm \mathrm{SD})\end{array}$ & & \\
\hline ICA & $\begin{array}{l}\text { SFV } \\
\text { DFV } \\
\text { VMEAN } \\
\text { RI } \\
\text { PI }\end{array}$ & $\begin{array}{l}360.74 \pm 55.87 \\
100.83 \pm 41.39 \\
230.78 \pm 42.39 \\
0.68 \pm 0.06 \\
1.03 \pm 0.13\end{array}$ & $\begin{array}{l}352.06 \pm 88.00 \\
112.21 \pm 26.60 \\
232.17 \pm 54.02 \\
0.72 \pm 0.10 \\
1.15 \pm 0.24\end{array}$ & $\begin{array}{l}-0.33 \\
1.00 \\
0.08 \\
1.82 \\
1.99\end{array}$ & $\begin{array}{l}0.74 \\
0.32 \\
0.93 \\
0.07 \\
0.05\end{array}$ \\
\hline $\mathrm{OA}$ & $\begin{array}{l}\text { SFV } \\
\text { DFV } \\
\text { VMEAN } \\
\text { RI } \\
\text { PI }\end{array}$ & $\begin{array}{l}328.86 \pm 80.31 \\
68.70 \pm 28.15 \\
198.76 \pm 50.68 \\
0.78 \pm 0.06 \\
1.26 \pm 0.17\end{array}$ & $\begin{array}{l}396.96 \pm 81.61 \\
89.12 \pm 34.24 \\
247.74 \pm 57.13 \\
0.79 \pm 0.06 \\
1.32 \pm 0.16\end{array}$ & $\begin{array}{l}2.48 \\
1.89 \\
2.65 \\
0.64 \\
0.98\end{array}$ & $\begin{array}{l}0.01 \\
0.06 \\
0.01 \\
0.52 \\
0.33\end{array}$ \\
\hline CRA & $\begin{array}{l}\text { SFV } \\
\text { DFV } \\
\text { VMEAN } \\
\text { RI } \\
\text { PI }\end{array}$ & $\begin{array}{l}235.82 \pm 58.04 \\
44.11 \pm 18.52 \\
139.97 \pm 36.10 \\
0.76 \pm 0.05 \\
1.94 \pm 2.66\end{array}$ & $\begin{array}{l}300.39 \pm 74.91 \\
70.29 \pm 21.61 \\
170.38 \pm 58.72 \\
0.82 \pm 0.06 \\
1.38 \pm 0.17\end{array}$ & $\begin{array}{l}2.79 \\
3.80 \\
1.78 \\
2.69 \\
-0.80\end{array}$ & $\begin{array}{l}0.01 \\
<0.001 \\
0.08 \\
0.009 \\
0.43\end{array}$ \\
\hline
\end{tabular}

$\mathrm{ICA}=$ internal carotid artery; $\mathrm{OA}=$ ophthalmic artery; $\mathrm{CRA}=$ central retinal artery; $\mathrm{SFV}=$ peak systolic flow velocity; $\mathrm{DFV}=\mathrm{end}$ diastolic flow velocity; VMEAN = mean flow; RI = resistivity index; PI = pulsatility index; ${ }^{\dagger}$ t-Student's t-test 
Table 2. Correlations between flow parameters for ophthalmic artery and central retinal artery, contrast sensitivity, and visual field parameters

\begin{tabular}{|l|l|l|l|l|l|}
\hline \multicolumn{2}{|c|}{} & \multicolumn{2}{l|}{$\begin{array}{l}\text { Flow parameters vs. } \\
\text { contrast sensitivity }\end{array}$} & \multicolumn{2}{l|}{$\begin{array}{l}\text { Flow parameters vs. } \\
\text { visual field }\end{array}$} \\
\hline \multirow{2}{*}{ Artery } & $\begin{array}{l}\text { Doppler ultrasound } \\
\text { parameter }\end{array}$ & $\begin{array}{l}\text { Correlation } \\
\text { coefficient }^{\dagger}\end{array}$ & p-value & $\begin{array}{l}\text { Correlation } \\
\text { coefficient }^{\dagger}\end{array}$ & p-value \\
\hline \multirow{5}{*}{ OA } & SFV & -0.35 & 0.03 & -0.34 & 0.04 \\
& DFV & -0.44 & 0.008 & -0.26 & 0.13 \\
& VMEAN & -0.43 & 0.009 & -0.39 & 0.01 \\
& RI & 0.28 & 0.09 & 0.20 & 0.23 \\
& PI & 0.33 & 0.04 & 0.25 & 0.13 \\
\hline \multirow{5}{*}{ CRA } & SFV & -0.36 & 0.030 & 0.02 & 0.02 \\
& DFV & -0.55 & $<0.001$ & 0.02 & 0.02 \\
& VMEAN & -0.23 & 0.18 & 0.12 & 0.12 \\
& RI & 0.50 & 0.002 & 0.22 & 0.19 \\
& PI & 0.31 & 0.06 & 0.09 & 0.59 \\
\hline
\end{tabular}

$\mathrm{OA}=$ ophthalmic artery; $\mathrm{CRA}=$ central retinal artery; $\mathrm{SFV}=$ peak systolic flow velocity; $\mathrm{DFV}=$ end diastolic

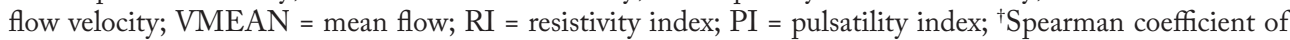
correlation

was a borderline positive correlation between pulsatility index and contrast sensitivity $(r=0.33 ; \mathrm{p}=0.046)$. For the OA, a negative correlation was found between the visual field results and peak systolic flow velocity $(\mathrm{r}=-034 ; \mathrm{p}=0.04)$ and mean flow $(\mathrm{r}=-0.39 ; \mathrm{p}=0.018)$. For the CRA, we found a significant negative correlation between the contrast sensitivity results and peak systolic flow velocity $(r=-0.36 ; p=0.03)$ and end diastolic flow velocity $(\mathrm{r}=-0.55 ; \mathrm{p}<0.001)$. In the CRA, there was a significant positive correlation between the resistance index and contrast sensitivity $(r=0.5$; $\mathrm{p}=0.002)$, as well as positive correlation between the visual field results and peak systolic $(r=0.023 ; p=0.023)$ and diastolic flow velocity $(\mathrm{r}=0.023 ; \mathrm{p}=0.023)$.

We performed ROC analysis to examine the screening sensitivity and specificity of Doppler ultrasound of the ICA, OA and CRA for detection of eDON. The results for each individual flow parameter used as a predictor of eDON are shown for all arteries.

According to ROC analysis, the CRA demonstrated the highest predictive potential for $\mathrm{eDON}$, whereas the other two arteries are weak predictors. Nevertheless, only the peak systolic flow velocity of the ICA showed visible deviation from the reference line. The inflection point of ROC curve indicated the area with satisfactory sensitivity and specificity $(70 \%$ sensitivity and $66 \%$ specificity).

\section{Discussion}

The present study found the orbital blood flow parameters to be significantly lower in patients with eDON than in those without eDON. According to our literature search, this is the first report on this subject. Kurioka et al. and Alp et al. have previously reported a significant difference in the flow rates in patients with TAO when compared to the flow rates of the general population ${ }^{14,15}$. They also found a significant correlation between the resistivity index and Barrett's muscle index (an index that quantifies extraocular muscle impingement on the optic nerve) $)^{14-16}$.

In this study, we examined the difference in orbital blood flow parameters between the patients with eDON and patients with active TAO that did not have signs of optic nerve damage. It is known that orbital blood flow may change secondary to the pathologic sequels of hyperthyroidism, which include increased systemic blood pressure, increased intraocular pressure, and orbital inflammation.

We found that the resistivity index, peak systolic flow velocity and end diastolic flow velocity for the CRA were significantly lower in the group of patients with eDON as compared with the control group without eDON. These findings could be explained by blood flow autoregulation mechanisms. In the group without 
eDON, a higher resistance in the CRA leads to higher flow rates. In patients with eDON, the decrease of blood flow is likely due to inflammatory damage in the orbital tissues. These changes in orbital blood flow may ultimately cause hypoxia and optic nerve damage.

We also found a positive correlation between the contrast sensitivity test results and the resistivity index for CRA, and between the visual field results and peak systolic and end diastolic flow velocities for CRA. These results, although surprising, show that in the early stage of DON, orbital blood flow exhibits great hemodynamic instability and damage to the optic nerve is still sufficient to cause clinically significant functional damage. Therefore, if we detect DON in its early stage and treat it appropriately, we could prevent permanent optic nerve damage. However, if DON is left untreated and reaches late stage, then irreversible damage to the optic nerve develops due to long-lasting hypoxia, which leads to permanent visual field defects and loss of visual acuity. In cases of recurrence, in older patients and in smokers, functional recovery of the optic nerve after DON is less probable, which confirms that hypoxia, as well as inflammation may be the principal pathogenic cause of permanent optic nerve damage.

Our ROC analysis showed that CRA flow had the highest predictive potential for detecting eDON, suggesting that the posterior ciliary arteries may also have a high predictive potential for detecting eDON. Future investigations could explore blood flow in the posterior ciliary arteries with more sensitive $10 \mathrm{MHz}$ ultrasound probes.

The advantage of color Doppler ultrasound examination of the orbital blood flow in detection of eDON is that it is not biased by patient compliance (compared to visual field and CST) and may be used even in patients not cooperative enough for cognitive visual tests.

It is known that patients with late DON have a higher resistivity index and higher velocity blood flow velocity in orbital vessels when compared with the general population ${ }^{15,16}$. We found that color Doppler ultrasound examination could detect orbital blood flow changes in these patients, with early cases of DON demonstrating lower velocity orbital blood flows, probably mostly due to orbital inflammation. It remains unknown whether irreversible damage to the optic nerve occurs at a specific blood flow cutoff point ${ }^{16}$. Additional studies may identify whether a quantifiable decrease in blood flow is associated with damage, as well as elucidate whether other factors contribute to nerve damage, such as inflammation, changes in orbital blood flow autoregulatory mechanisms, and genetically determined susceptibility of optic nerve fibers. Future studies should also examine the effect of corticosteroid therapy in patients with eDON to determine its use as a possible treatment to prevent irreversible optic nerve damage.

\section{References}

1. Ambrosio G, Ferrara G, Vitale R, De Marco R. Visual evoked potentials in patients with Graves' ophthalmopathy complicated by ocular hypertension and suspect glaucoma or dysthyroid optic neuropathy. Doc Ophthalmol. 2003;106:99-104.

2. Gorman CA. Pathogenesis of Graves' ophthalmopathy. Thyroid. 1994;4:379-83.

3. Riley FC. Orbital pathology in Graves' disease. Mayo Clinic Proc. 1972;47:975-9.

4. Prummel MF, Bakker A, Wiersinga WM, Baldeschi L, Mourits M P, Kendall-Taylor P, et al. Multi-center study on the characteristics and treatment strategies of patients with Graves' orbitopathy: the first European Group on Graves' Orbitopathy experience. Eur J Endocrinol. 2003;148:491-5. doi: 10.1530/eje.0.1480491

5. Kahaly GJ, Pitz S, Hommel G, Dittmar M. Randomized, single blind trial of intravenous versus oral steroid monotherapy in Graves' orbitopathy. J Clin Endocrinol Metab. 2005;90: 5234-40. doi: 10.1210/jc.2005-0148

6. Neigel JM, Rootman J, Belkin RI, Nugent RA, Drance SM, Beattie CW, et al. Dysthyroid optic neuropathy. The crowded orbital apex syndrome. Ophthalmology. 1988;95:1515-21.

7. van Geest RJ, Sasim IV, Koppeschaar HP, Kalmann R, Stravers SN, Bijlsma WR, et al. Methylprednisolone pulse therapy for patients with moderately severe Graves'orbitopathy: a prospective, randomized, placebo-controlled study. Eur J Endocrinol. 2008;158:229-37. doi: 10.1530/EJE-07-0558

8. McKeag D, Lane C, Lazarus JH, Baldeschi L, Boboridis K, Dickinson AJ, et al. Clinical features of dysthyroid optic neuropathy: a European Group on Graves' Orbitopathy (EUGOGO) survey. Br J Ophthalmol. 2007;91:455-8. doi: 10.1136/bjo.2006.094607

9. Suttorp-Schulten MS, Tijessen R, Mourits MP, Apkarijan P. Contrast sensitivity function in Graves' ophthalmopathy and dysthyroid optic neuropathy. Br J Ophthalmol. 1993;77: 709-12.

10. Dickinson AJ, Perros P. Controversies in the clinical evaluation of active thyroid-associated orbitopathy: use of a detailed protocol with comparative photographs for objective assessment. Clin Endocrinol (Oxf). 2001;55:283-303. doi: $10.1046 / \mathrm{j} .1365-2265.2001 .01349$ 
11. Benning H, Lieb W, Kahaly G, Grehn F. Color duplex ultrasound findings in patients with endocrine orbitopathy. Ophthalmologe. 1994;91:20-5.

12. Nakase Y, Osanai T, Yoshikawa K, Inoue Y. Color Doppler imaging of orbital venous flow in dysthyroid optic neuropathy. Jpn J Ophthalmol. 1994;38:80-6.

13. Mourits MP, Prummel MF, Wiersinga WM, Koornneef L. Clinical activity score as a guide in the management of patients with Graves' ophthalmopathy. Clin Endocrinol (Oxf). 1997; 47:9-14.
14. Kurioka Y, Inaba M, Kawagishi T, Emoto M, Kumeda Y, Inoue $\mathrm{Y}$, et al. Increased retinal blood flow in patients with Graves' disease: influence of thyroid function and ophthalmopathy. Eur J Endocrinol. 2001;144:99-107. doi: 10.1530/eje.0.1440099

15. Alp MN, Ozgen A, Can I, Cakar P, Gunalp I. Colour Doppler imaging of the orbital vasculature in Graves' disease with computed tomographic correlation. Br J Ophthalmol. 2000;84:1027-30.

16. Budimir I, Demirović A, Iveković R, Pažanin L. Epithelioid hemangioma of the orbit: case report. Acta Clin Croat. 2015 Mar;54(1):92-5.

Sažetak

$$
\begin{gathered}
\text { POREMEĆAJI CIRKULACIJE U KRVNIM ŽILAMA ORBITE } \\
\text { DIJAGNOSTICIRANI OBOJENIM DOPPLEROVIM ULTRAZVUKOM } \\
\text { KOD BOLESNIKA S RANIM STADIJEM DISTIROIDNE OPTIČKE NEUROPATIJE }
\end{gathered}
$$

\author{
M. Lešin, V. Rogošić, L. Vanjaka Rogošić, I. Barišić i G. Pelčić
}

Problemi štitnjače i povezane orbitopatije (TAO) najčešća su manifestacija Gravesove bolesti. Cilj ove studije bio je objasniti 6\% bolesnika s TAO kod kojih se razvila distiroidna optička neuropatija (DON), koja je ujedno najozbiljnija komplikacija TAO. S obzirom na to da DON može izazvati trajno oštećenje vida, vrlo ga je važno rano prepoznati dok je vidna funkcija još očuvana i reverzibilna. Obojeni Dopplerov ultrazvuk je neinvanzivna dijagnostička metoda koja je vrlo djelotvorna u ranom otkrivanju DON-a. U studiju je bilo uključeno 36 bolesnika s dijagnosticiranom Gravesovom bolesti i TAO-om, od kojih je 21 (58\%) bolesnik imao rani DON (early DON, eDON), dok 15 (42\%) bolesnika nije imalo znakova eDON-a. Svakom ispitaniku učinjen je obojeni Dopplerov ultrazvuk kako bi se odredio stupanj protoka krvi (cirkulacije) u unutarnjoj karotidnoj arteriji, oftalmičkoj arteriji i središnjoj retinalnoj arteriji. Rezultati su pokazali da pregled obojenim Dopplerovim ultrazvukom ima visok potencijal u ranoj dijagnostici promjena cirkulacije u orbiti kod bolesnika $s$ ranim eDON-om. Rano otkrivanje DON-a može pomoći u ranijem liječenju i prevenciji trajnog oštećenja vidnoga živca. ozljede

Ključne riječi: Gravesova oftalmopatija; Gravesova bolest; vidni živac, bolesti; ultrazvučno snimanje, kolor dopler; vidni živac, 